\title{
Analysis of Rainfall and Temperature Trends and Variability in Semi-arid North-eastern Ethiopia
}

\author{
Abate Getachew Feleke ${ }^{1, *}$, Mulualem Abera ${ }^{2}$ \\ ${ }^{1}$ National Meteorological Agency of Ethiopia, Meteorological Research and Studies Directorate, Addis Ababa, Ethiopia \\ ${ }^{2}$ National Meteorological Agency of Ethiopia, Meteorological Data Archive and Climatology Directorate, Addis Ababa, Ethiopia
}

Email address:

abateyy@yahoo.com (A. G. Feleke)

${ }^{*}$ Corresponding author

\section{To cite this article:}

Abate Getachew Feleke, Mulualem Abera. Analysis of Rainfall and Temperature Trends and Variability in Semi-arid North-eastern Ethiopia. International Journal of Environmental Monitoring and Analysis. Vol. 8, No. 4, 2020, pp. 75-87. doi: 10.11648/j.ijema.20200804.11

Received: March 31, 2020; Accepted: April 23, 2020; Published: August 27, 2020

\begin{abstract}
Northeast Ethiopia is a semi-arid region that exhibits high rainfall and temperature variability. The impact of climate change has received a great deal of attention worldwide. This study focused on detecting trends in in rainfall (1983-2013) and temperature (1981-2010) at annual, seasonal and monthly time scales for six weather stations in semiarid north eastern Ethiopia. The study also aimed to determine dry spell length, number of rainy days, onset and cessation dates, and length of growing period. The non-parametric tests such as Mann-Kendall and Sen's Slope were used to determine climatic trends. The results indicated that both the annual maximum and minimum temperature in the study region showed an increasing trend, but only the trend for maximum temperature was significant. In the same manner, both the Belg and Kiremt seasons maximum and minimum temperature also showed an increasing trend but only trend of maximum temperature during Belg season and trend of minimum and maximum temperature during Kiremt seasons was significant. The annual and Belg season rainfall in the region showed a decreasing trend and its trend was significant. The coefficient of rainfall variability for annual and Belg season was very high which could affect agricultural production in the region. In the contrary, the trend for Kiremt season rainfall was increasing without significant trend. On the other hand, the average length of dry spell during the Kiremt season in the region was generally long that ranged from 27 days to 39 days and showed both decreasing and increasing but with no significant trend in most stations. The number of annual rainy days also showed both increasing and decreasing trends but its trend was not significant. The length of growing period in the region was relatively stable at all stations during the last 30 years period without non-significant trend. In general, from the analysis of annual, seasonal and monthly rainfall and temperature data series it can be concluded that rainfall and temperature characteristics of the study area is changing, even though some of the trends on both parameters were not statistically significant.
\end{abstract}

Keywords: Climate Variability, Dry Spell, LGP, Mann-kendall, Rainfall, Trend

\section{Introduction}

Agriculture is very sensitive to climatic and, more generally, environmental conditions [36]. In Ethiopia, agriculture remains the most important sector of the economy. The contribution of agriculture to the national economies through food supply, employment creation, export earnings, etc. is enormous $[9,14]$, but it is predominantly rain-fed. The sector plays a dominant role in the economy of Ethiopia, contributing $41 \%$ GDP, $80 \%$ of the employment and the majority of foreign exchange earnings [16]. The success of agricultural production has, therefore, large implications, ranging from the state of the countrywide economy to the survival of the subsistence farmers [4].

Global average surface temperature is expected to increase by 1.4 to $5.8^{\circ} \mathrm{c}$ over the period 1990 to 2100 [21]. This warming is expected to have a significant impact on the precipitation regime and water availability. These changes in precipitation are likely to be accompanied by an increase in its variability [21] and along with the projected 
increase in atmospheric $\mathrm{CO}_{2}$ concentration will directly affect plant growth and development and consequently crop yields [36]. A greenhouse gas induced climate change would very likely result in significant changes in crop production which could have major socio-economic impacts. Regional climate conditions are a primary determinant of agricultural productivity as plant metabolic processes are regulated by such variables as temperature, solar radiation, carbon dioxide $\left(\mathrm{CO}_{2}\right)$, and water availability [10, 25]. Agricultural productivity can also be disrupted due to damage to crops caused by climate extremes, such as heat waves, storms, droughts, and flooding [6]. Climate of the Earth varies across temporal and spatial scales throughout the planet. Large areas of the earth represent variability as a part of their normal climate over both short and long time periods [15]. These climatic variations will have unexpected consequences with respect to frequency and intensity of precipitation and temperature variability for many regions of the Earth.

Air temperature and precipitation are principle element of weather systems, so that examination of their behavior is important for understanding of climate variability because both are highly variable spatially and temporarily at different local, regional and global scales. For the prediction of future climate conditions, level of variability of these two weather elements must be examined and understood. Therefore, recently, the focus on climate variability bases mostly on the detection of trends in instrumental records of precipitation and temperature. Several researches of climatic trends have recently been conducted on rainfall and temperature data at different periods of records throughout the world [37]. As temperature and precipitation are fundamental components of climate, hence changes in their pattern can affect human health, ecosystems, plants, and animals [28]. An increase in temperature can result in heat wave incidents and cause illness and death in susceptible populations. Changes in precipitation and temperature forms and their timing can have widespread effect on the availability of water and can cause a shift in animal and plant species [38]. Increases in precipitation trends can also result in an increase in the frequency of floods and could thereby impact water quality. Precipitation is a vital part of the hydrologic cycle and changes in its pattern would directly influence the water resources of the concerned region. Changes in rainfall quantity and frequency would alter the pattern of stream flows and demands (particularly agricultural), spatial and temporal distribution of runoff, soil moisture, and groundwater reserves. The two variables, temperature and precipitation, are also interconnected. [19] examined the impact of rainfall variability on the Ethiopian economy, and found that rainfall variability in the country led to a production deficit of $20 \%$ and increased in poverty rates by $25 \%$ which costed the economy over one-third of its growth potential. In general, changes in rainfall conditions have a direct and immediate impact on the performance of agricultural sector as well as on the country's total GDP [14 and 20].
Trend analysis of rainfall in different spatial and temporal scales could lead to a better understanding of the problems associated with floods, droughts, and the availability of water for various uses with respect to future climate scenarios. For example, a decrease in precipitation trend could imply an increase in instances of drought. On the other hand, an increase in Earth's temperature leads to more evaporation and cloud formation to occur, which in turn, increases precipitation [34].

Previous studies were conducted mostly at regional level and information regarding rainfall and temperature trends, variabilities as well as other rainfall characteristics were lacking. Hence, the objective of this study was to assess trends and variability of rainfall and temperature in the semiarid north eastern Ethiopia. The study also aimed to determine dry spell length, number of rainy days, onset and cessation dates, and length of growing period in the study region.

\section{Materials and Methods}

\subsection{Description of the Study Area}

The study was conducted in north-eastern Ethiopia during 2015. The study area is characterized by a semi-arid type of climate. The rainy season of the area is bimodal where the short rainy season (Belg) stretches from February to May and the main rainy season (Kiremt) from June to September. The study area is also characterized by rugged mountains consisting of low lands, mid lands and high lands. Thirty years of historical meteorological data (rainfall and temperature) within the study area (Alamata, Maichew, Lalibela, Kobo, Sirinka and Kombolcha weather stations) were collected for the analysis of variability and trend in monthly, seasonal and annual rainfall and temperature in the study region.

\subsection{Data Collection and Compilation}

Monthly and daily rainfall and temperature data of 30 years (1981-2010) for temperature and (1983-2013) for rainfall data were obtained from the National Meteorological Service Agency (NMSA) of Ethiopia and from the respective weather stations in the study region. The stations were selected based on the length of a record period and the relative completeness of the data. The world meteorological organization has recommended 30 years as a minimum data required for searching evidence of climatic change in hydroclimatic time series [22]. To reconstruct the gap and to fill missing values, data were be generated following the first order Markov chain model using INSTAT plus (v3.6) software [33]. Then, the generated data was checked for their physical representatives of the respective stations. INSTAT plus software was also used to summarize the daily data into annual, monthly and seasonal totals and to analyze the onset and cessation of the rainy season and length of growing period (LGP).

Identification of outliers (suspicious data) was the 
primary emphasis to the climate database development [17]. For non-normally distributed data like rainfall, the Tukey fence is recommended for trimming the outlier [27]. There are different methodologies to analyze homogeneity. In this particular study cumulative deviation test was used for absolute testing (using stations own data). This method was commonly used in the climatology to detect nonhomogeneities in the meteorological time series. [8] noted that tests for homogeneity can be based on the adjusted partial sums or cumulative deviations from the mean. Time series data required for trend analysis should be random and/or non-persistent [27]. One of the problems in the analysis and interpretation of trends in hydrological data is the confounding effect of serial dependence. Furthermore, in the presence of positive serial correlation, the nonparametric test could signify a significant trend due to random effects of the data series [24]. In this study, before proceeding to trend analysis, the time series data was tested for randomness and independence using the autocorrelation function.

\subsection{Analyses of Patterns and Trends in Annual and Seasonal Rainfall and Temperature}

Seasonal and annual rainfall and temperature totals were computed from daily data. In this study, Mann-Kendall's test and Sen's estimator of slope were employed to determine trends. Mann-Kendall's test is a non-parametric method, which is less sensitive to outliers and tests for a trend in a time series without specifying whether the trend is linear or nonlinear [39]. Sen's estimator test is applied in cases where the trend is assumed to be linear, depicting the quantification of changes per unit time. This method could be used with missing data and remain unaffected by outliers or gross errors [23]. Then, the slope (change per unit time) was estimated for both rainfall and temperature data. Based on the earlier procedure trends of annual, seasonal (Kiremt and Belg) and monthly (February-September) totals as well as rainfall characteristics such as onset date, cessation date, LGP, number of rainy days and dry spell length were determined.

\subsection{Analysis of Onset and Cessation Dates, Number of Rainy Days, Dry Spell Length and Rainfall Variability}

Different authors use different threshold values to determine the onset of the rain. The criterion used in this study was a rainfall of $20 \mathrm{~mm}$ or more accumulated over three consecutive rainy days after a specified date with no dry spell greater than 7 days in the next 30 days [35]. Moreover, the end of the season was defined as the date when the available soil water content dropped to $10 \mathrm{~mm} \mathrm{~m}^{-1}$ of available water [35]. This date was set based on previous studies and farmers' information obtained during preliminary survey. The length of growing period was calculated as a difference between the onset date and date of the end of the season. Based on the definition of National Meteorological Service Agency of Ethiopia, a day is considered as a rainy day if it accumulates $1 \mathrm{~mm}$ or more rainfall [26]. Thus numbers of rainy days were counted starting from the first day of June to September 30 (Kiremt season) in each year. Moreover, maximum number of consecutive dry days (a day that accumulate rainfall $<1 \mathrm{~m}$ ) were counted to determine dry spell length in Kiremt season. Standardized anomaly index, precipitation concentration index, and coefficient of variation were used as descriptors of rainfall variability [2]. Standardized Anomaly Index (SAI) was calculated as the difference between the annual total of a particular year and the long term average rainfall records divided by the standard deviation of the long term data. This index was used to examine the nature of the trends and enables the determination of the dry and wet years in the record.

\section{Results and Discussions}

\subsection{Annual and Seasonal Rainfall Regimes}

The result indicated that rainfall in the semi-arid northeastern Ethiopia is generally low that varies slightly from 731 $\mathrm{mm}$ at Alamata to $1087 \mathrm{~mm}$ at Kombolcha (Table 1). The result also indicated that the main rainy season (Kiremt rainfall) contributes largely to the annual rainfall totals. The contribution to the annual total from the main season, however, varies across weather stations that range from $64 \%$ to $77 \%$ depending on the site of the location. The short rainy season (Belg), however, contributes relatively small amount to the annual total at all weather stations that ranges from $21 \%$ to $27 \%$. Previous studies in the Amhara regional state of Ethiopia also indicated that the main season (Kiremt) and the short rainy season (Belg) had contributed 55-85\% and 8$24 \%$, respectively to the annual rainfall totals [2, 3]. [18] also reported that the main rainy season (Kiremt) contributes largely to the annual rainfall totals in all stations in northern Ethiopia that ranges from $50-90 \%$ depending on the site of the location and the Belg rainfall also makes a considerable contribution to the annual rainfall totals in some areas such as Adigrat (29\%), Edagahamus (31\%) and Alamata (36\%).

The coefficient of variation in most of weather stations in north-eastern Ethiopia showed that rainfall in the region has high inter-annual variability (Table 2). The result also showed that annual rainfall variability at all locations $(\mathrm{CV}=$ $16 \%-20 \%$ ) was relatively low. The inter-annual rainfall variability for the Kiremt season was relatively high $(\mathrm{CV}>20 \%)$ across all weather stations. On the other hand, the inter-annual rainfall variability for Belg season was very high $(\mathrm{CV}>40 \%)$ across all weather stations. Comparing the seasonal variability of rainfall in the region, Belg rainfall is the most variable than the Kiremt season and annual rainfall. [3] also reported moderate inter annual variability of Kiremt rainfall in the Amhara regional state of Ethiopia. Both the Kiremt and Belg seasons rainfall has direct impact on agricultural production in north-eastern Ethiopia. Hence, such high variability in short and Kiremt rainfall could tremendously affect the livelihood of the farming community in the region. Hence, emphasis should be given to use crop 
management strategies that help to reduce the adverse effect of climate variability in the region. [30] reported that the rainfall variability over the central highland of Ethiopia during the Kiremt season was associated with the equatorial eastern Pacific sea level pressure, the southern oscillation index and the sea surface temperature (SST) over the tropical eastern Pacific Ocean. These authors further noted that the SST over the tropical eastern Pacific Ocean is negatively correlated with Kiremt rainfall. Moreover, analysis of PCI value revealed that all stations have values ranged from $16 \%$ $18 \%$ (Table 2). Based on the scale defined in [11], all the stations in the study region are grouped under high concentration of monthly rainfall distribution which indicates poor monthly rainfall distribution in the region. Similar results were reported by $[3,2]$ wherein the rainfall in the Amhara region of Ethiopia is characterized by high to very high monthly concentration. [18] also reported that all the stations in northern Ethiopia are grouped under high and very high concentration which indicates poor monthly distribution of the rainfall.

Table 1. Average seasonal (short and main seasons) rainfall contributions to annual rainfall totals in North-eastern Ethiopia, 1992-2013.

\begin{tabular}{llll}
\hline Stations & $\begin{array}{l}\text { Annual rainfall } \\
(\mathbf{m m})\end{array}$ & $\begin{array}{l}\text { Belg rainfall } \\
(\mathbf{m m})\end{array}$ & $\begin{array}{l}\text { Kiremt rainfall } \\
(\mathbf{m m})\end{array}$ \\
\hline Alamata & 731 & $187(26 \%)$ & $465(64 \%)$ \\
Maichew & 776 & $198(26 \%)$ & $494(64 \%)$ \\
Lalibela & 892 & $187(21 \%)$ & $625(70 \%)$ \\
kobo & 774 & $212(27 \%)$ & $474(61 \%)$ \\
Sirinka & 994 & $254(26 \%)$ & $637(64 \%)$ \\
Kombolcha & 1087 & $256(24 \%)$ & $733(77 \%)$ \\
\hline
\end{tabular}

Table 2. Coefficient of variation for annual and seasonal (short and main seasons) rainfall and mean PCI values for the period 1981-2010 in Northeastern Ethiopia.

\begin{tabular}{lllll}
\hline Stations & $\begin{array}{l}\text { Annual rainfall } \\
(\mathbf{m m})\end{array}$ & $\begin{array}{l}\text { Belg rainfall } \\
(\mathbf{m m})\end{array}$ & $\begin{array}{l}\text { Kiremt rainfall } \\
(\mathbf{m m})\end{array}$ & PCI (\%) \\
\hline Alamata & 0.20 & 0.44 & 0.31 & 17 \\
Maichew & 0.19 & 0.41 & 0.30 & 16 \\
Lalibela & 0.16 & 0.40 & 0.24 & 18 \\
kobo & 0.20 & 0.44 & 0.31 & 16 \\
Srinka & 0.18 & 0.43 & 0.25 & 16 \\
Kombolcha & 0.17 & 0.42 & 0.23 & 17 \\
\hline
\end{tabular}

\subsection{Analysis of Standardize Anomaly Index (SAI)}

Analysis of the standard anomaly index for the weather stations is depicted in Figure 1. The rainfall pattern in the studied stations exhibited certain characteristics that a dry year is followed by another two or three dry years and vis-àvis for the wet years. The study revealed that many of the stations have experienced drought during 1983-1988 and 2003-2013. Generally, for the period 1983-2013, the number of years recorded below the long term average at Alamata, Maichew, Lalibela, Kobo, Sirinka and Kombolcha stations were $40,50,53,37,40$ and $43 \%$, respectively. It was also observed that the frequency occurrence of below normal rainfall at all locations has been increased in the last decade. In this regard $60 \%-80 \%$ of the years in the recent decade had recorded below long term average in all stations. Moreover, during the last 30 years, 1984 was the driest years at all weather stations considered in this study. Similarly, [3, 2] and [18] had used SAI to demonstrate the intensity and frequency of drought at various time scales and reported as helpful to indicate the drought characteristics.
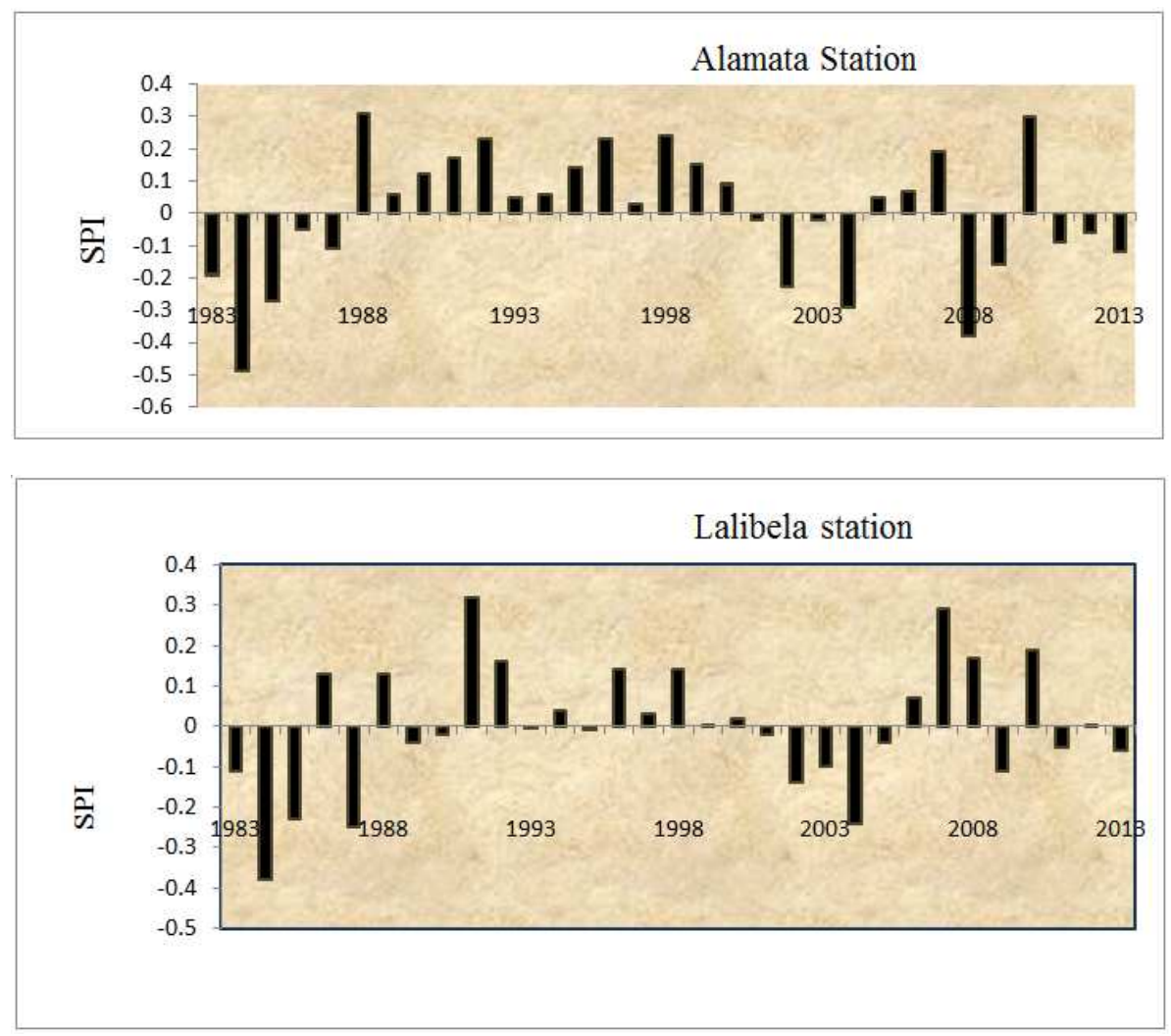

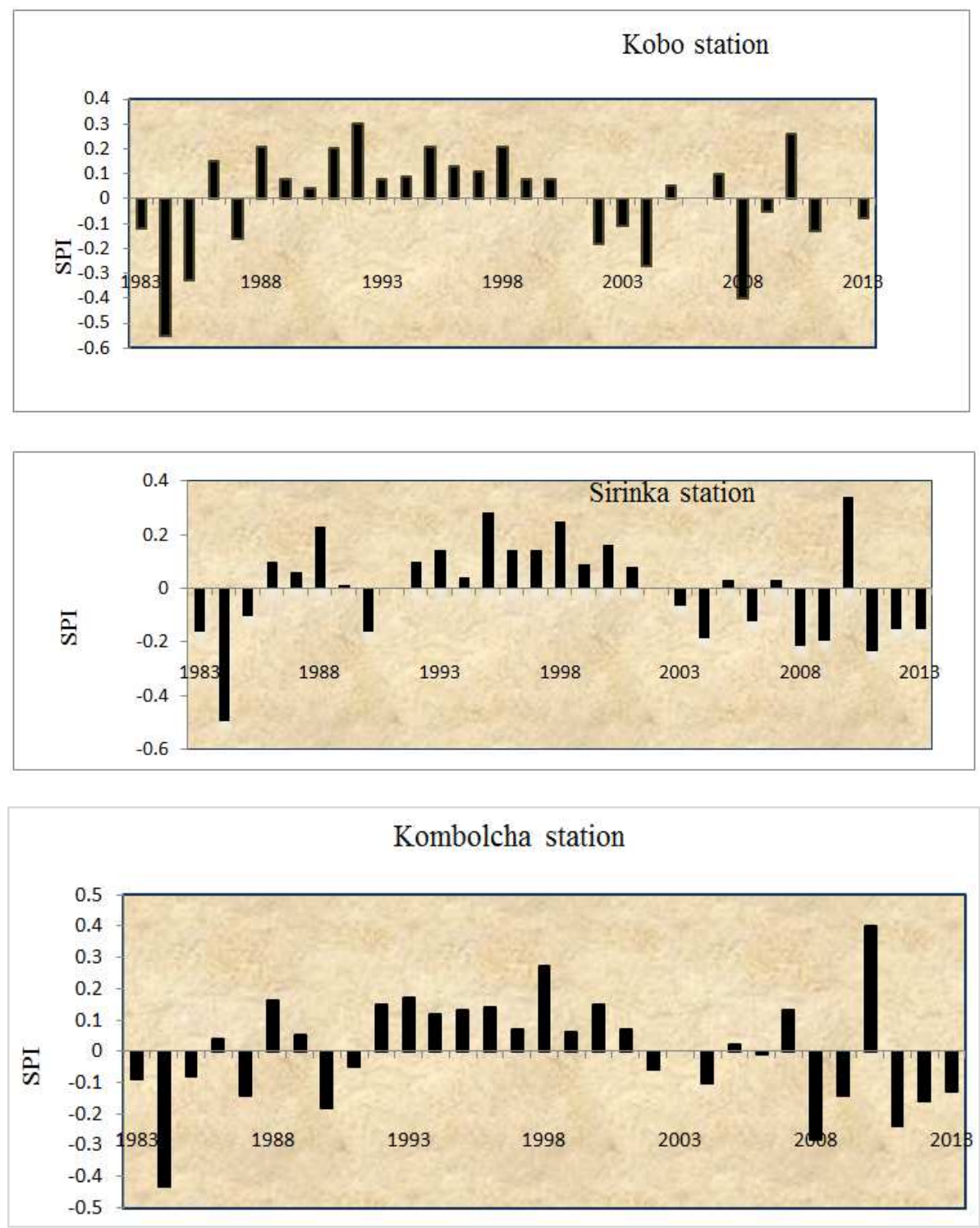

Figure 1. Standardized time series plot of annual rainfall totals of six stations in northeast Ethiopia over the period 1983-2013.

\subsection{Analysis of Annual and Seasonal Rainfall Trends}

Trend analysis was also performed on seasonal and annual scale to examine if there are trends in the data at this scale. The annual rainfall in the study region as a whole showed a decreasing trend (Figure 2) and its trend was statistically significant. Similarly, the Belg season rainfall in the region showed a decreasing trend (Figure 3) and it was statistically significant at $5 \%$ probability level. In the contrast, the Kiremt season rainfall in the study region showed an increasing trend (Figure 4), however, its trend was not statistically significant at $5 \%$ probability level. The Mann-Kendall trend test also showed a decreasing trend of annual rainfall in all of weather stations considered in this study (Table 3). The result also indicated that during the last thirty years period, annual rainfall had decreased by 43,68 , 90, 135 and $81 \mathrm{~mm}$, at Alamata, Maichew, Kobo, Sirinka and Kombolcha weather stations, respectively, but, annual rainfall was increased by $48 \mathrm{~mm}$ at Lalibela Station.
However, both the decreasing and increasing trends of annual rainfall totals at all weather stations were not statistically significant at $5 \%$ probability level. This might be attributed more to the large inter-annual variability of rainfall in the region. For example, at all weather stations, the 1980 s were generally a dry period relative to preceding decade and rainfall has recovered to more wet conditions during the 1990s that again decreased to below long term average in the 2000s (Figure 1). This result agrees with the findings of $[13,30,12,40]$ and [18] indicated a nonsignificant trend of annual rainfall totals in northern Ethiopia.

On the other hand, the analysis of the Man Kendal trend test on Kiremt rainfall revealed that all weather stations showed an increasing trend. However, this increasing trend of Kiremt season rainfall totals at all weather stations except Lalibela station were not statistically significant (Table 3). In the contrary, all stations showed a decreasing trend of Belg season rainfall (Table 3) and the Man Kendal trend test 
revealed statistically significant at 5\% probability level for all stations. In general, in the last 30 years, Kiremt season rainfall has been increased by $137 \mathrm{~mm}, 128 \mathrm{~mm}, 238 \mathrm{~mm}$, $129 \mathrm{~mm}, 104 \mathrm{~mm}$ and $130 \mathrm{~mm}$ at Alamata, Maichew, lalibela, Kobo, Sirinka and Kombolcha stations, respectively. On the contrary, Belg season rainfall in the last 30 years was decreased by $135 \mathrm{~mm}, 122 \mathrm{~mm}, 115 \mathrm{~mm}, 155 \mathrm{~mm}, 155 \mathrm{~mm}$ and $165 \mathrm{~mm}$ for the respective weather stations in the region. This decreased in Belg season rainfall adversely affected the
Belg growing areas in the region and ultimately reduce agricultural production and productivity. Hence, irrigation, soil and water conservation practices and other climate change adaptation options could be helpful to reduce the adverse impact of drought in the region during the Belg season. At the same time, selection of appropriate crops and their verities could have positive impact to minimize the adverse effect of drought in this region.

Table 3. Trends of annual and seasonal (short and main seasons) rainfall totals in north-eastern Ethiopia for the period 1983-2013.

\begin{tabular}{|c|c|c|c|c|c|c|}
\hline \multirow{2}{*}{ Stations } & \multicolumn{2}{|l|}{ Annual } & \multicolumn{2}{|c|}{ Belg season } & \multicolumn{2}{|c|}{ Kiremt season } \\
\hline & zmk & slope & Zmk & slope & Zmk & slope \\
\hline Alamata & $-0.03^{\mathrm{ns}}$ & -1.42 & $-0.35^{*}$ & -4.5 & $0.17^{\mathrm{ns}}$ & 4.58 \\
\hline Maichew & $-0.08^{\mathrm{ns}}$ & -2.25 & $-0.29^{*}$ & -4.05 & $0.13^{\mathrm{ns}}$ & 4.25 \\
\hline Lalibela & $0.07^{\mathrm{ns}}$ & 1.61 & $-0.31^{*}$ & -3.84 & $0.26^{*}$ & 7.93 \\
\hline Kobo & $-0.10^{\mathrm{ns}}$ & -3.00 & $-0.29^{*}$ & -5.17 & $0.16^{\mathrm{ns}}$ & 4.29 \\
\hline Sirinka & $-0.14^{\mathrm{ns}}$ & -4.53 & $-0.36^{*}$ & -5.17 & $0.15^{\mathrm{ns}}$ & 3.47 \\
\hline
\end{tabular}

ZMK is Mann-Kendall trend test, Slope (Sen's slope) is the change (mm)/annual; ns is non-significant trend at 0.05 and * indicats significant trend at 0.05 significant level.

\subsection{Monthly Rainfall Trend}

Considering rainfall during months of both the short and main rainy season (February to September), the short season rainfall totals showed a decreasing trend at all stations for February, March, April and May (Table 4) However, the Mankendal trend test was not statistically significant at 5\% probability level except the month of May at Alamata. In the contrarily, the monthly rainfall totals during the main season at all weather stations showed an increasing trend at all stations for June, July and August (Table 4). However, a decreasing trend was observed for the month of September for all stations except at Alamata. The Mankendal trend test showed that the increasing trend of rainfall totals for June was not statistically significant at $5 \%$ at all locations. On the other hand, the increasing trend of rainfall during July was statistically significant for all weather stations except Sirinka station. The Mankendal trend test also revealed that the decreasing rainfall trend during September at Kobo, Sirinka and Kombocha was statistically significant while it was not significant for Alamata, Maichew and lalibela stations. The decreasing trend of rainfall during September indicated that the length of the growing period (LGP) might be shortened that ultimately increase terminal drought which affect agricultural production and productivity in the region.

Table 4. Sen's estimator of slope (mm/year) for monthly rainfall (short and main seasons) in north-eastern Ethiopia.

\begin{tabular}{|c|c|c|c|c|c|c|c|c|}
\hline Stations & Feb. & Mar. & Apr. & May & Jun. & Jul. & Aug. & Sep. \\
\hline Alamata & $0.27^{\mathrm{ns}}$ & $-1.00^{\mathrm{ns}}$ & $-0.04^{\mathrm{ns}}$ & $-1.60^{*}$ & $0.17^{\mathrm{ns}}$ & $3.90^{*}$ & $2.06^{\mathrm{ns}}$ & 0.86 \\
\hline Maichew & $-0.29^{\text {ns }}$ & $-1.00^{\mathrm{ns}}$ & $0.24^{\mathrm{ns}}$ & $-1.38^{\text {ns }}$ & $0.54^{\mathrm{ns}}$ & $3.14^{*}$ & $1.23^{\mathrm{ns}}$ & $-1.00^{\mathrm{ns}}$ \\
\hline Lalibela & $-0.30^{\mathrm{ns}}$ & $-0.80^{\mathrm{ns}}$ & $0.00^{\mathrm{ns}}$ & $-1.54^{\mathrm{ns}}$ & $1.00^{\mathrm{ns}}$ & $4.11^{*}$ & $2.84^{*}$ & $-1.14^{\mathrm{ns}}$ \\
\hline Kobo & $-0.50^{\mathrm{ns}}$ & $-1.00^{\mathrm{ns}}$ & $0.14^{\mathrm{ns}}$ & $-1.39 \mathrm{~ns}$ & $0.37^{\mathrm{ns}}$ & $2.89^{*}$ & $2.24^{\mathrm{ns}}$ & $-1.13^{*}$ \\
\hline Sirinka & $-0.65^{\mathrm{ns}}$ & $-0.70^{\mathrm{ns}}$ & $-1.00^{\mathrm{ns}}$ & $-1.44^{\mathrm{ns}}$ & $0.46^{\mathrm{ns}}$ & $4.00^{\mathrm{ns}}$ & $0.75^{\mathrm{ns}}$ & $-2.55^{*}$ \\
\hline Kombolcha & $-1.00^{\mathrm{ns}}$ & $-0.96^{\mathrm{ns}}$ & $-1.20^{\mathrm{ns}}$ & $-0.75^{\text {ns }}$ & $0.70^{\mathrm{ns}}$ & $4.62^{*}$ & $2.00^{\mathrm{ns}}$ & $-2.67^{*}$ \\
\hline
\end{tabular}

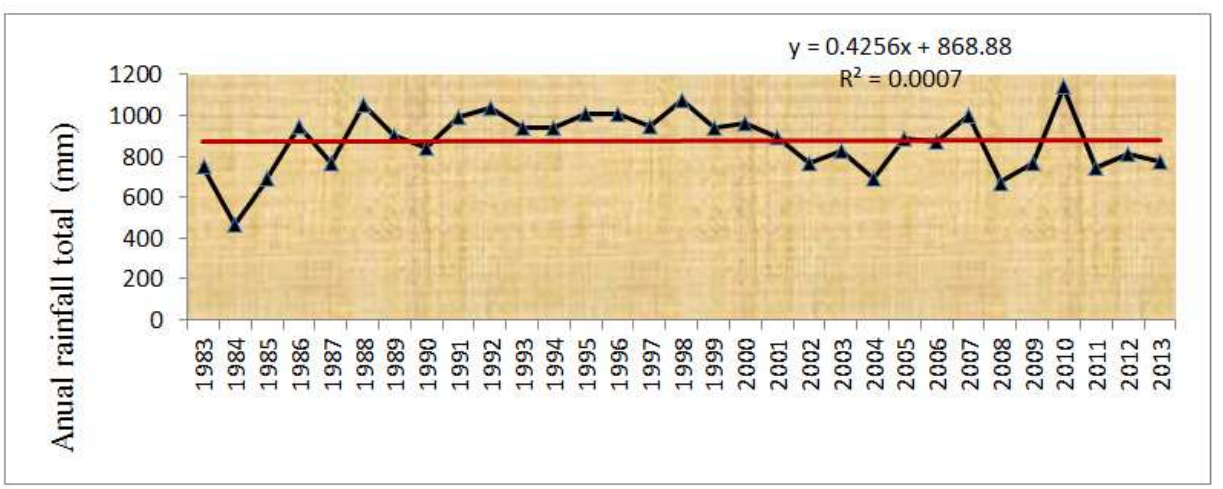

Figure 2. Annual rainfall total trend in northeast Ethiopia (1983-2013). 


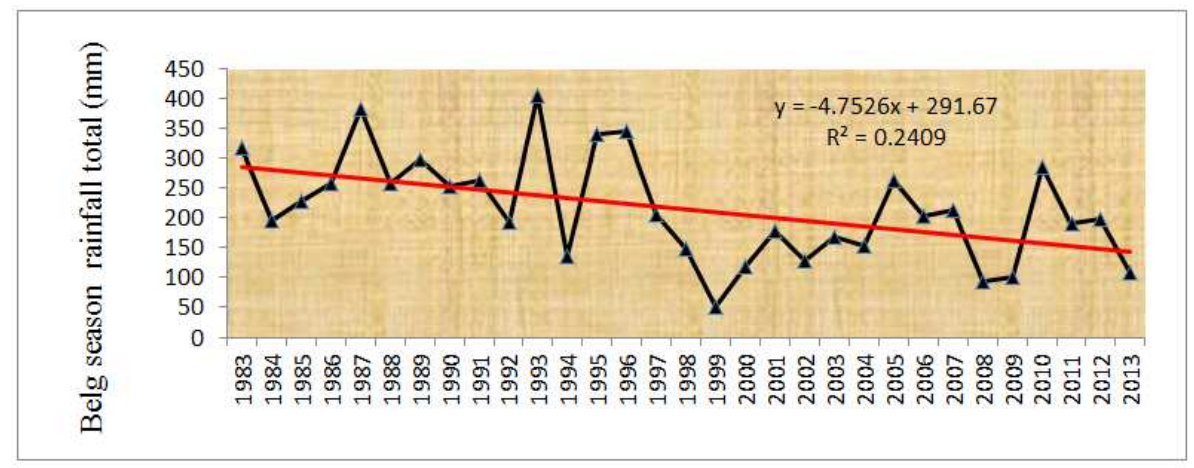

Figure 3. Belg season total rainfall trend (1983-2013) in northeast Ethiopia.

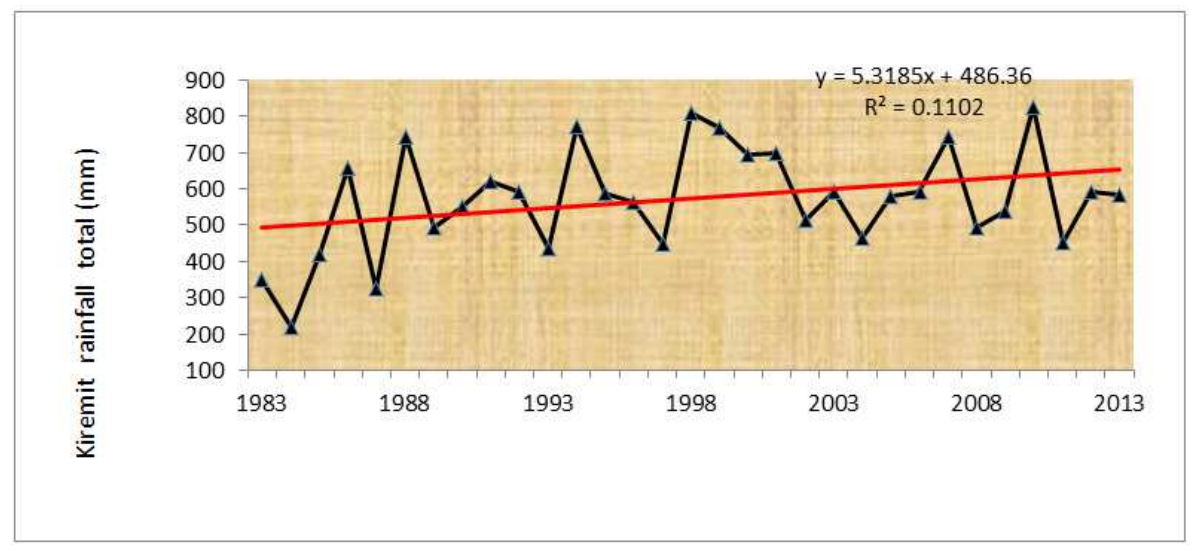

Figure 4. Keremt season total rainfall trend (1983-2013) in northeast Ethiopia.

\subsection{Analysis of Rainfall Onset Date}

The median for onset of Kiremt rainfall is similar in all stations and it begins on the first week of July (Table 5). It was also characterized with relatively low standard deviation ( $<8$ days). This low standard deviation implies that patterns could be easily understood and consequently decisions pertaining to crop planting and related activities in the study region might be stable. The result also indicated that the onset date in the last 30 years was not significantly changed at all stations. However, this might be due to higher interannual variability of Kiremt rainfall in the study region. In contrast to this finding, [18] reported a significant change in onset date of Kiremt season in northern Ethiopia. This difference might be due to high inter-annual variability of Kiremt rainfall in the study region. And also the numbers of weather stations considered in this study were small as compared to other studies. On the other hand, our result agrees with the finding of Araya and Stroosnijder (2011) who reported that the onset of Kiremt rainfall at Alamata, Adigudum, Maichew and Mekelle in northern Ethiopia was the first decade of July.

\subsection{Analysis of Rainfall Cessation Date}

The growing season in the studied stations has ended starting from September-14 to September-20 (Table 5). In agreement with this result, [1] and [18] had also reported similar findings in northern Ethiopia. Our result also indicated that Kiremt season rainfall has ceased early in the northeast part of the region. The median date of the end of the Kiremt season had characterized by low standard deviation ( $<10$ days) at lalibela and Kombolcha stations and hence it can be generalized that the end of rainy season in these stations is relatively stable. In contrast, end of the Kiremt season at Kobo and Sirinka stations showed high standard deviation (about 28 days at Kobo and 18 days at Sirinka), which implies difficulty in estimating the pattern of the end of the rainy season. Hence, careful decisions on crop management and related activities are required to manage terminal drought which affect crops and other farm activities. In addition, some of the stations have showed a decreasing trend in cessation of Kiremt rainfall.

Table 5. Statistical characteristics and trends of onset date, cessation date and LGP at six stations over the period 1983-2013 in Northeast Ethiopia.

\begin{tabular}{llllll}
\hline $\begin{array}{l}\text { Rainfall } \\
\text { characteristics }\end{array}$ & Statistics & Lalibela & Kobo & Sirinka & kombolcha \\
\hline \multirow{4}{*}{ Onset date } & Median & Jul-7 & Jul-10 & Jul-7 & Jul-8 \\
& ZMK & $0.04^{\text {ns }}$ & $0.23^{\text {ns }}$ & $0.12^{\text {ns }}$ & $-0.01^{\text {ns }}$ \\
& slope & 0.00 & 0.41 & 0.08 & 0.00 \\
& SD & 4.31 & 8.40 & 5.06 & 7.26 \\
Cessation date & Median & Sep-16 & Sep-14 & Sep-20 & Sep-18 \\
& ZMK & $-0.23^{\text {ns }}$ & $0.17^{\text {ns }}$ & $0.22^{\text {ns }}$ & $-0.12^{\text {ns }}$ \\
& slope & 0.00 & 0.00 & 0.00 & 0.00 \\
& SD & 0.49 & 27.68 & 17.7 & 1.14 \\
& Median & 76 & 77 & 74 & 73 \\
& ZMK & $-0.04^{\text {ns }}$ & $-0.06^{\text {ns }}$ & $-0.12^{\text {ns }}$ & $-0.1^{\text {ns }}$ \\
& slope & 0.00 & 0.16 & -0.08 & 0.00 \\
& SD & 4.31 & 26.75 & 5.06 & 7.47 \\
& CV $(\%)$ & 6.57 & 35.00 & 6.84 & 11.71 \\
\hline
\end{tabular}




\subsection{Analysis of Length of Growing Period (LGP)}

The Length of Growing Period (LGP) is the length of time (in days) that enough moisture is available in the soil for (rainfed) plant growth and the mean daily temperature is above $5^{\circ} \mathrm{C}$. Average length of growing period in the study region varies from 74-77 days depending on the location of the station (Table 5). The result indicated that all the weather stations had comparatively similar length of growing period that ranges from 73 days -77 days. However, the coefficient of variation at Kobo was high $(\mathrm{CV}=35 \%)$ that showed high year to year variability of LGP. On the other, hand, the rest of stations had recorded low coefficient of variation $(\mathrm{CV}<11 \%)$ that indicated relatively stable conditions in LGP in the study region. Regarding the direction of trend, only Kobo station had showed an increasing trend in LGP while the LGP at Sirinka showed a decreasing trend. However, both the increasing and the decreasing trends in LGP at both stations were not statistically significant. On the other hand, the LGP at Lalibela and Kombolcha stations had showed neither decreasing nor increasing trend. Hence, it can be concluded that the LGP at these stations was relatively stable during the last 30 years period. In similar study, [18] reported that average length of growing period in northern Ethiopia varies from 66-85 days depending on the location of the station. His report also indicated that. The coefficient of variation at Alamata (28\%) and Edagahamus (29\%) also showed high year to year variability of LGP.

\subsection{Analysis of Number of Rainy Days}

The number of annual rainy days observed in the study region varies from 44 days at Kobo station to 64 days at Lalibela station. Average number of annual rainy days and maximum dry spell length observed in Kiremt season at four stations over the period 1983-2013 is depicted in Table 7 . The number of rainy days at Lalibela and Kombolcha showed an increasing trend while the trend at Kobo and Sirinka was decreasing. Based on the Mankendall's trend test, both the positive and negative trends, however, were not statistically significant at $5 \%$ probability level. Similar result to this study, [18] reported that the number of annual rainy days at Mekelle was 61 days and its trend was nonsignificant over the period 1981-2009. Previous study by [30] had also reported non-significant trend of rainy days from ten stations in Ethiopia. Regarding the inter-annual variability, number of rainy days recorded at all stations showed lower variability i.e. Kobo $(\mathrm{CV}=17.8)$, Kombolcha $(\mathrm{CV}=12)$, lalibela $(\mathrm{CV}=9.6)$ and Sirinka $(\mathrm{CV}=12)$.

\subsection{Analysis of Dry Spell Length}

The average length of dry spell during the Kiremt season in semi-arid north-eastern Ethiopia was generally long that ranged from 27 days at Kobo to 39 days at Sirinka (Table 6). It has been indicated that the average length of dry spell during Kiremt season had higher standard deviation ( $>15$ days) in most of the stations studied (Table 6), but it was low at Lalibela (6.8 days). The higher standard deviation revealed that the dry spells occurs at irregular interval at each year so that it could be difficult to plan and manage agricultural activities during the crops growth period. Our result further revealed that the dry spell length during Kiremt season has shown an increasing trend at Kobo and Sirinka while it showed a decreasing trend at lalibela and Kombolcha. The Mankendall trend test indicated that the increasing trend in dry spell length at Kobo was statistically significant whereas the trend for the rest of stations was not significant at 5\% probability level. Hence, it could be important to apply crop management practices that retain soil moisture in the crop rooting depth which could minimize adverse effect of intermittent drought that occur during the growing period. In agreement with this result, Seleshi and [31] and [18] reported that longer dry spell was observed in the northern part of the country. From the current result, we can conclude that under semi-arid areas where interannual and interseasonal rainfall variability is high, analysis of trends in rainfall events such as onset date, cessation date, LGP, dry spell length and number of rainy days might be more important than the annual and seasonal totals as the distribution of rainfall during the season is more important for agricultural production than the total rainfall in the season.

Table 6. Statistical characteristics and trends of dry spell length and rainy days at five stations over the period 1980-2009 in Northern Ethiopia.

\begin{tabular}{llllll}
\hline $\begin{array}{l}\text { Rainfall } \\
\text { characteristics }\end{array}$ & Statistics & Lalibela & Kobo & Sirinka & kombolcha \\
\hline \multirow{4}{*}{ Rainy days } & Median & 64 & 44 & 56 & 61 \\
& ZMK & $0.21^{\text {ns }}$ & $-0.28^{\text {ns }}$ & $-0.18^{\text {ns }}$ & $0.12^{\text {ns }}$ \\
& slope & 0.33 & -0.53 & -0.33 & 0.09 \\
& SD & 6.30 & 8.60 & 6.80 & 7.5 \\
Dry spell length & Median & 31 & 27 & 39 & 37 \\
(days) & ZMK & $-0.02^{\text {ns }}$ & $0.49^{*}$ & $0.15^{\text {ns }}$ & $-0.05^{\text {ns }}$ \\
& slope & 0.00 & 1.08 & 0.52 & -0.11 \\
& SD & 6.80 & 20.21 & 25.10 & 16.20 \\
& CV $(\%)$ & 20.60 & 56 & 57.60 & 37.20 \\
\hline
\end{tabular}

\subsection{Analysis of Annual and Seasonal Temperature Trends}

Both the annual maximum and minimum temperature in the study region showed an increasing trend (Figure 5 and Figure 6). However, only the annual maximum temperature trend was statistically significant at $5 \%$ probability level. In the same manner, both the Belg and Kiremt season maximum temperature showed an increasing trend (Figure 7 and Figure 9) but only the trend during the Belg season was statistically significant. On the other hand, the minimum temperature during the Belg and Kiremt seasons (Figure 8 and Figure 10) also showed an increasing trend, however, none of the trends were significant at $5 \%$ probability level. Seasonal and annual maximum temperature as well as their trends is presented in Tabel 7 for the period 1981-2010. The analysis of annual maximum temperature for the period 1981-2010 showed an increasing trend for most of stations except Alamata and the trend is statistically significant for most of stations except Alamata and lalibela. On the other hand, the annual minimum temperature showed a decreasing trend in most of 
the stations except Lalibela and its trend was statistically significant for Maichew station only. In contrast, the trend for annual minimum temperature at Lalibela was positive and its trend was statistically significant. In the same manner, the maximum temperature during the Belg season showed an increasing trend in all of the stations and the trend was statistically significant for most of the stations except Lalibella (Table 7). On the other hand, the minimum temperature during the Belg season showed a decreasing trend for most stations except Lalibela station and its trend was statistically significant only for Maichew station. The maximum temperature during the Kiremt season, however showed both decreasing and increasing trends based on the location of the station. Increasing trend was observed for Maichew, Kobo and Sirinka stations whereas decreasing trend was observed for Alamata, Lalibela and Kombolcha stations. However, statistically significant trend was observed for Lalibela and Sirinka stations only. The minimum temperature during the Kiremt season also showed increasing trend for Lalibela, Kobo and Sirinka stations but showed a decreasing trend for Alamata, Maichew and Kombolcha stations. However, statistically significant trend was observed for Maichew and Lalibela stations only.

Table 7. Sen's estimator of slope $\left({ }^{\circ} \mathrm{C}\right.$ lyear) for annual and seasonal (short and main seasons) of maximum and minimum temperature in north-eastern Ethiopia.

\begin{tabular}{|c|c|c|c|c|c|c|}
\hline \multirow{2}{*}{ Stations } & \multicolumn{2}{|c|}{ Annual Temperature. } & \multicolumn{2}{|c|}{ Belg season Temperature. } & \multicolumn{2}{|c|}{ Kiremt season Temperature } \\
\hline & Maximum $\left({ }^{\circ} \mathrm{C}\right)$ & Minimum $\left({ }^{\circ} \mathrm{C}\right)$. & Maximum $\left({ }^{\circ} \mathrm{C}\right)$ & Minimum $\left({ }^{\circ} \mathrm{C}\right)$ & Maximum $\left({ }^{\circ} \mathrm{C}\right)$ & Minimum $\left({ }^{\circ} \mathrm{C}\right)$ \\
\hline Alamata & $-5.051 \mathrm{E}-4^{\mathrm{ns}}$ & $-0.047^{\text {ns }}$ & $0.05^{\text {ns }}$ & $-0.035^{\text {ns }}$ & $-0.077^{\mathrm{ns}}$ & $-0.065^{\mathrm{ns}}$ \\
\hline Maichew & $0.057 *$ & $-0.05 *$ & $0.114^{*}$ & $-0.056^{*}$ & $0.005^{\mathrm{ns}}$ & $-0.041^{*}$ \\
\hline Lalibela & $1.709 \mathrm{E}-4^{\mathrm{ns}}$ & $0.09^{*}$ & $0.031 *$ & $0.11 *$ & $-0.031^{*}$ & $0.044 *$ \\
\hline Kobo & $0.05^{*}$ & $-0.004^{\mathrm{ns}}$ & $0.105^{*}$ & $-0.014^{\mathrm{ns}}$ & $0.021^{\mathrm{ns}}$ & $0.002^{\mathrm{ns}}$ \\
\hline Sirinka & $0.08 *$ & $0.008^{\mathrm{ns}}$ & $0.135^{*}$ & $-0.003^{\mathrm{ns}}$ & $0.06^{*}$ & $0.012^{\mathrm{ns}}$ \\
\hline Kombolcha & $0.06^{*}$ & $-0.03^{\mathrm{ns}}$ & $0.09 *$ & $-0.04^{\mathrm{ns}}$ & $-0.009^{\text {ns }}$ & $-0.017^{\mathrm{ns}}$ \\
\hline
\end{tabular}

\subsection{Analysis of Monthly Maximum Temperature Trend}

All stations showed an increasing trend in maximum temperature during the month of February, March, April and May during the last 30 years period 9 Table 8). The increasing trend during February was statistically significant for most of stations except Lalibela. Similar trend was followed during March and April but its trend was not significant for Alamata and Lalibela Stations. Similarly, all the stations showed an increasing trend in maximum temperature during the month of May and its trend was significant except Lalibela station (Table 8). On the other hand, Alamata and Lalibela stations showed a decreasing trend in maximum temperature during the month of June and its trend was not significant at 5\% probability level. The rest of the stations showed an increasing trend during the month of June and the trend was significant only for Kobo and Sirinka stations. All the stations showed a decreasing trend of maximum temperature during the month of July and the trend was only significant for Alamata and lalibela stations only. A decreasing trend was observed for Alamata, Lalibela and Kombolcha stations during the month of August and none of the trends were significant. A significant increasing trend was observed for Sirinka station only during the month of September.

Table 8. Sen's estimator of slope $\left({ }^{\circ} \mathrm{C} /\right.$ year) for monthly maximum temperature (short and main seasons) in north-eastern Ethiopia.

\begin{tabular}{|c|c|c|c|c|c|c|c|c|}
\hline Stations & Feb. & Mar. & Apr. & May & Jun. & Jul. & Aug. & Sep. \\
\hline Alamata & $0.10^{\mathrm{ns}}$ & $0.07^{\mathrm{ns}}$ & $0.05^{\text {ns }}$ & $0.02^{*}$ & $-0.02^{\mathrm{ns}}$ & $-0.09^{*}$ & $-0.08^{\text {ns }}$ & $-0.1^{*}$ \\
\hline Maichew & $0.12^{*}$ & $0.11^{*}$ & $0.11^{*}$ & $0.08^{*}$ & $0.06^{\mathrm{ns}}$ & $-0.03^{\mathrm{ns}}$ & $0.008^{\text {ns }}$ & $0^{\text {ns }}$ \\
\hline Lalibela & $0.06^{*}$ & $0.04^{\mathrm{ns}}$ & $0.01^{\mathrm{ns}}$ & $0.04^{\mathrm{ns}}$ & $-0.02^{\mathrm{ns}}$ & $-0.07^{*}$ & $-0.03^{\mathrm{ns}}$ & $-0.04^{\mathrm{ns}}$ \\
\hline Kobo & $0.12^{*}$ & $0.12^{*}$ & $0.11^{*}$ & $0.09^{*}$ & $0.07^{*}$ & $-0.01^{\mathrm{ns}}$ & $0.003^{\mathrm{ns}}$ & $0.02^{\text {ns }}$ \\
\hline Sirinka & $0.15^{*}$ & $0.14^{*}$ & $0.13^{*}$ & $0.10^{*}$ & $0.09^{*}$ & $0.05^{\mathrm{ns}}$ & $0.06^{*}$ & $0.07^{*}$ \\
\hline Kombolcha & $0.07 *$ & $0.09^{*}$ & $0.12^{*}$ & $0.09^{*}$ & $0.05^{\mathrm{ns}}$ & $-0.03^{\mathrm{ns}}$ & $-0.01^{\mathrm{ns}}$ & $0.03^{*}$ \\
\hline
\end{tabular}

\subsection{Analysis of Monthly Minimum Temperature Trend}

All weather stations showed a decreasing trend in minimum temperature during the month of February except Lalibela station which showed a significant increasing trend (Table 9). The decreasing trend in minimum temperature during February was not statistically significant. Similar trend was followed during the month of March except the decreasing trend at Sirinka station was significant. A decreasing trend was observed during the month of April for Alamata, Maichew and Kombolcha stations. However, none of the decreasing and increasing trends were significant during this month. Similar trend also followed during the month of May except that the increasing trend at Lalibela station was significant. The trend during the month of June was exactly similar to the trend during the month of April. During the month of July, most of the stations except Lalibela and Sirinka showed a decreasing trend, however, none of the trends except Maichew station was significant. In the contrast, most of the stations except Alamata and Maichew showed an increasing trend during the month of August and none of the trends were significant. During the month of September, Alamata, Maichew and Kobo stations showed decreasing trend, however, statistically significant trend was observed at Maichew station only. 
Table 9. Sen's estimator of slope $\left({ }^{\circ} \mathrm{C} /\right.$ year) for monthly minimum temperature (short and main seasons) in north-eastern Ethiopia.

\begin{tabular}{|c|c|c|c|c|c|c|c|c|}
\hline Stations & Feb. & Mar. & Apr. & May & Jun. & Jul. & Aug. & Sep. \\
\hline Alamata & $-0.06^{\mathrm{ns}}$ & $-0.05^{\mathrm{ns}}$ & $-0.02^{\mathrm{ns}}$ & $-0.02^{\mathrm{ns}}$ & $-0.03^{\mathrm{ns}}$ & $-0.05^{\mathrm{ns}}$ & $-0.06^{\mathrm{ns}}$ & $-0.12^{\mathrm{ns}}$ \\
\hline Maichew & $-0.09^{\text {ns }}$ & $-0.07^{\mathrm{ns}}$ & $-0.03^{\text {ns }}$ & $-0.03^{\text {ns }}$ & $-0.01^{\mathrm{ns}}$ & $-0.05^{*}$ & $-0.04^{\mathrm{ns}}$ & $-0.06^{*}$ \\
\hline Kobo & $-0.04^{\mathrm{ns}}$ & $-0.01^{\mathrm{ns}}$ & $0.02^{\mathrm{ns}}$ & $0.02^{\mathrm{ns}}$ & $0.03^{\mathrm{ns}}$ & $-0.01^{\mathrm{ns}}$ & $0.01^{\mathrm{ns}}$ & $-0.03^{\mathrm{ns}}$ \\
\hline Sirinka & $-0.03^{\mathrm{ns}}$ & $-0.04 *$ & $0.02^{\mathrm{ns}}$ & $0.03^{\text {ns }}$ & $0.04^{\mathrm{ns}}$ & $0.01^{\mathrm{ns}}$ & $0.00^{\mathrm{ns}}$ & $0.02^{\mathrm{ns}}$ \\
\hline Kombolcha & $-0.03^{\text {ns }}$ & $-0.04^{\mathrm{ns}}$ & $-0.02^{\mathrm{ns}}$ & $-0.002^{\mathrm{ns}}$ & $-0.005^{\mathrm{ns}}$ & $-0.03^{\mathrm{ns}}$ & $0.003^{\mathrm{ns}}$ & $0.02^{\mathrm{ns}}$ \\
\hline
\end{tabular}

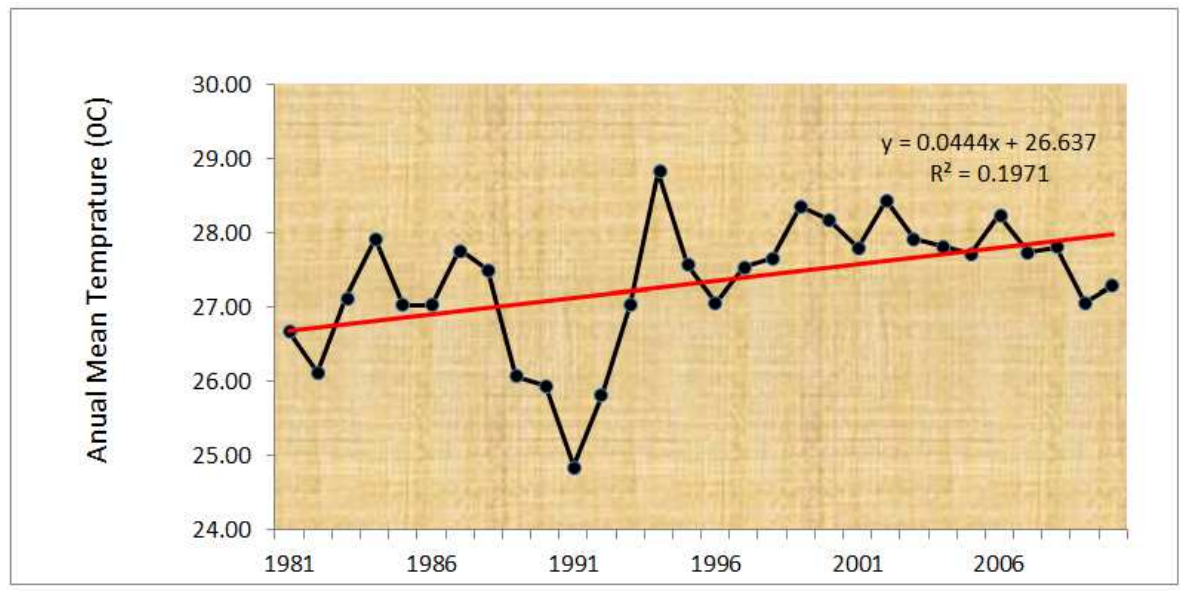

Figure 5. Annual maximum temperature trend (1981-2010) in northeast Ethiopia.

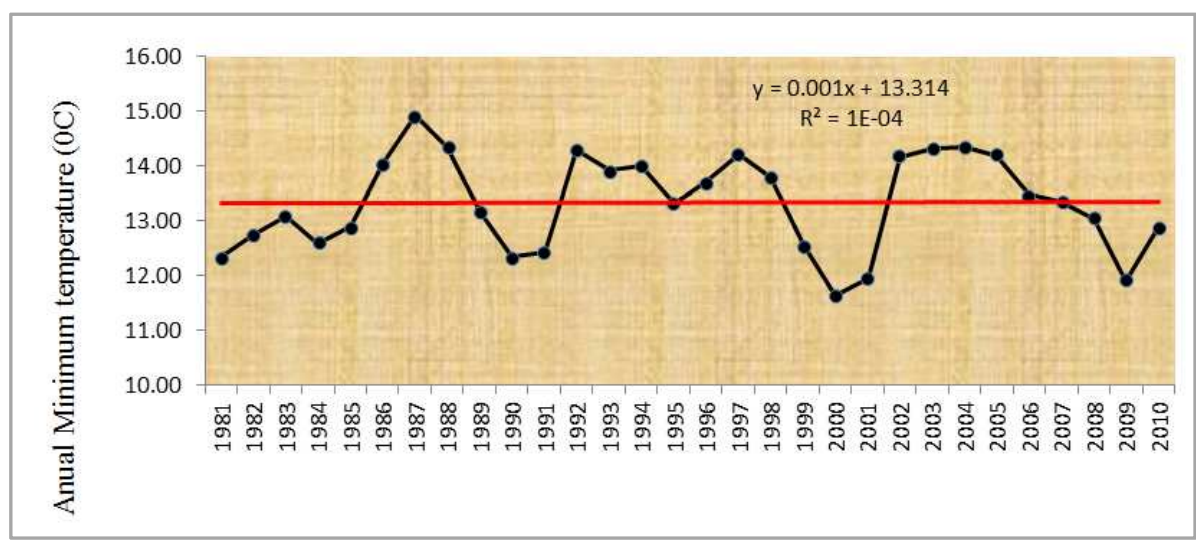

Figure 6. Annual minimum temperature trend (1981-1983) in northeast Ethiopia.

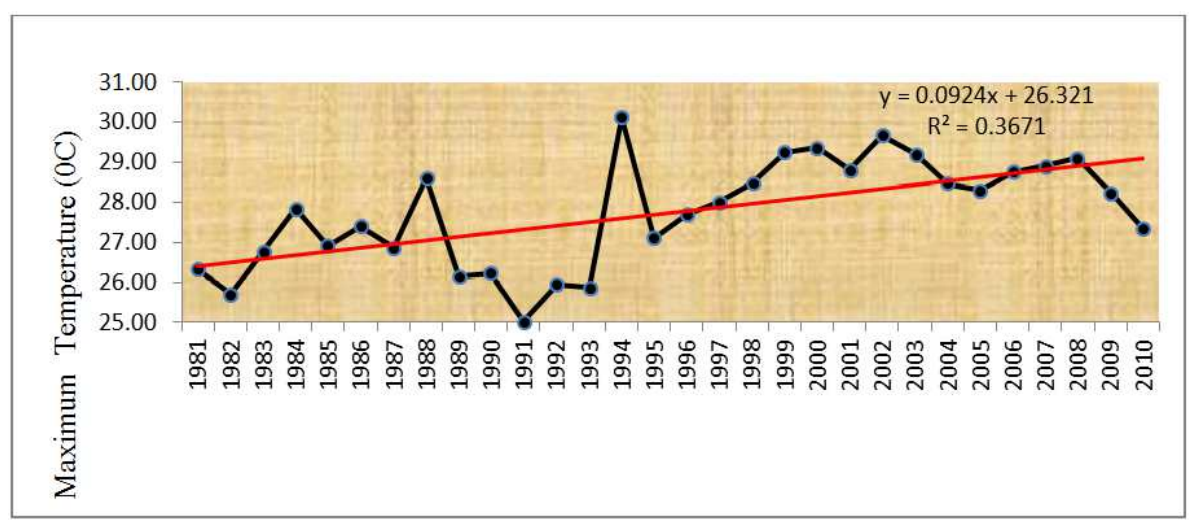

Figure 7. Kiremt season maximum temperature trend (1981-2010) in northeast Ethiopia. 


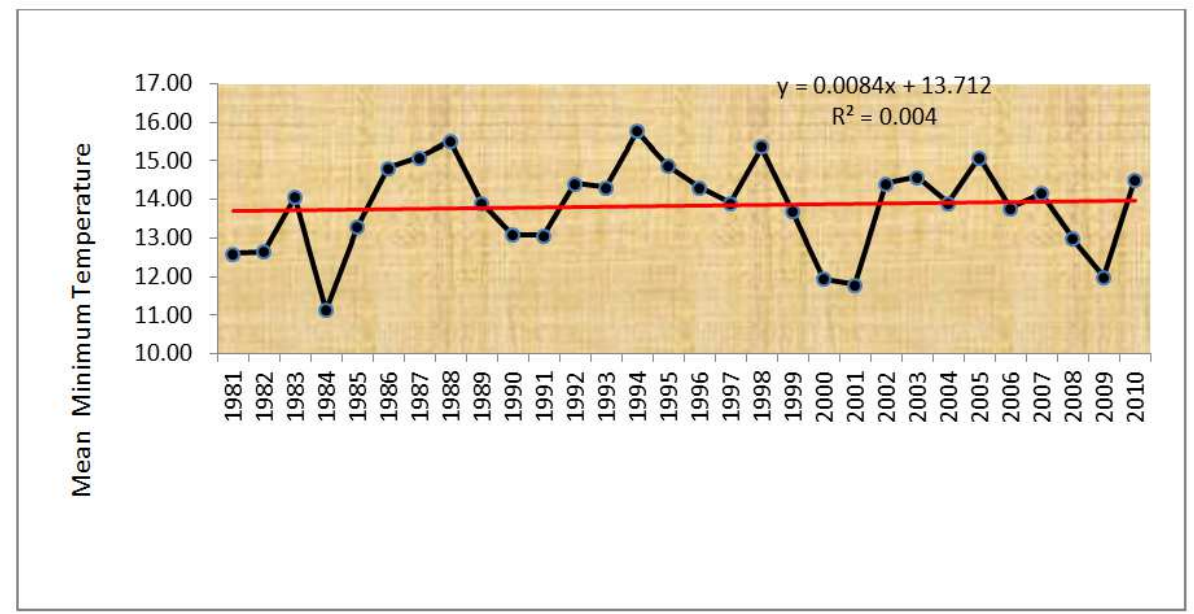

Figure 8. Kiremt Season minimum temperature trend (1981-2010) in northeast Ethiopia.

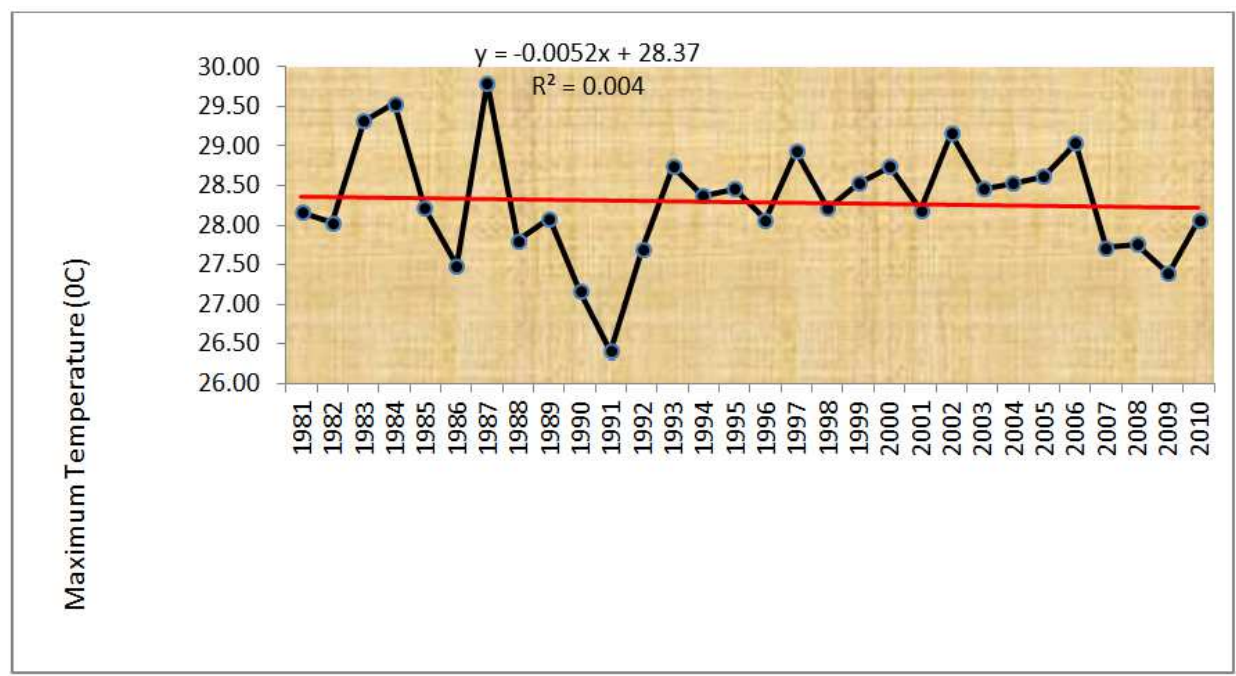

Figure 9. Belg Season maximum temperature trend (1981-1983) in northeast Ethiopia.

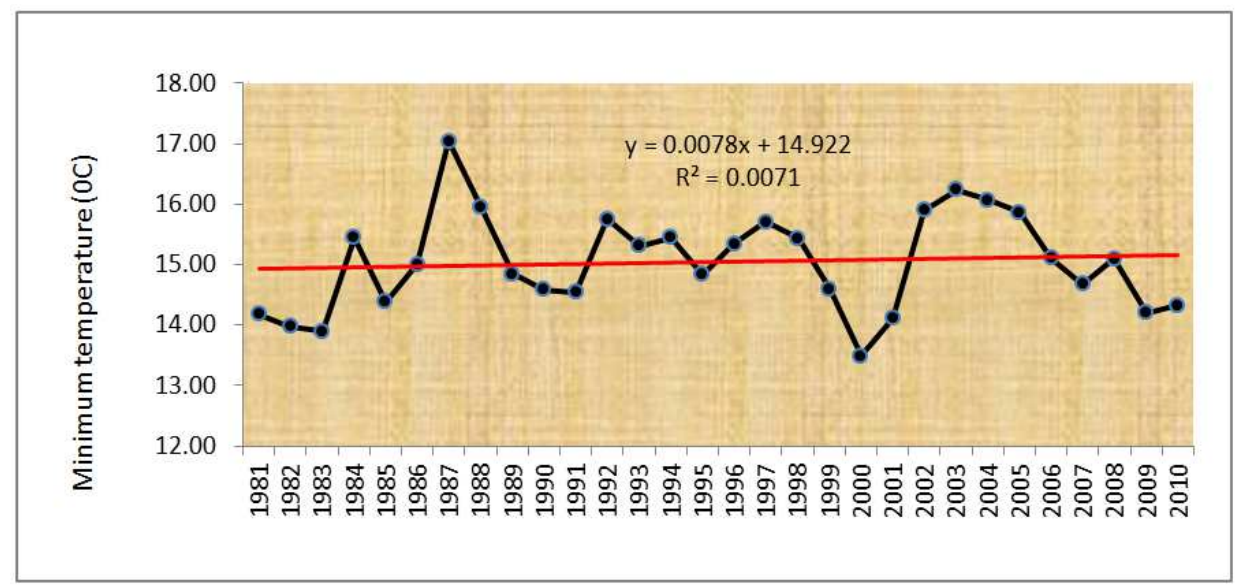

Figure 10. Mean Belg season minimum temperature trend (1981-2010) in northeast Ethiopia.

\section{Conclusions}

The impact of climate change has received a great deal of attention worldwide. This study focused on detecting trends in rainfall (1983-2013) and temperature (1981-2010) at annual, seasonal and monthly time scales for six weather stations in north-eastern Ethiopia. The study also aimed to determine dry spell length, number of rainy days and onset and cessation dates. The result indicated that rainfall in the 
semi-arid north-eastern Ethiopia is generally low that varies slightly from $731 \mathrm{~mm}$ to $1087 \mathrm{~mm}$. The main rainy season (Kiremt rainfall) contributes largely to the annual rainfall totals in the study region. The contribution to the annual total from the main season varies across weather stations that range from $64 \%$ to $77 \%$. The short rainy season (Belg) rainfall contributes relatively small amount to the annual total at all weather stations that ranges from $21 \%$ to $27 \%$.

The Man Kendall trend test indicated that annual and Belg season rainfall total for the period 1983-2013 showed a decreasing trend in all-weather stations in the study region but only the trend for Belg season was statistically significant. In contrast, the Kiremt season rainfall totals in all stations showed an increasing trend but it was not statistically significant for most stations. The analysis of annual maximum temperature for the period 1981-2010 showed an increasing trend for most of stations and its trend was statistically significant for most of stations. In contrast, the minimum temperature showed a decreasing trend in most of the stations. In the same manner, the maximum temperature during the Belg season showed an increasing trend in all of the stations and its trend was statistically significant for most of the stations. The minimum temperature during the Belg season, however, showed a decreasing trend for most stations and its trend was not significant for most stations. The maximum temperature during the Kiremt season showed both negative and positive trend based on the location of the stations. From analysis of annual, seasonal and monthly rainfall and temperature data series it can be concluded that rainfall and temperature characteristics of the study area is changing, even though some of the trends on both parameters were not statistically significant.

\section{References}

[1] Araya, A. Stroosnijder, L. (2011). Assessing drought risk and irrigation need in northern Ethiopia. Agric. Forest Meteorol. 151: 425-436.

[2] Ayalew, D., Tesfaye, K., Mamo, G. Yitaferu, B. Bayu, W. (2012). Variability of rainfall and its current trend in Amhara region, Ethiopia. Afr. J. Agric. Res. 7 (10): 1475-1486. http://dx.doi.org/10.5897/AJAR11.698.

[3] Bewket, W. and Conway, D. (2007). A note on the temporal and spatial variability of rainfall in the drought-prone Amhara region of Ethiopia. Int. J. Climatol. 27: 1467-477. http://dx.doi.org/10.1002/joc.1481.

[4] Block, P., and Rajagopalan, B. (2007). Interannual variability and ensemble forecast of upper Blue Nile basin Kiremt season precipitation. Am. Meteorol. Soc. 8: 327-343. http://dx.doi.org/10.1175/JHM580.1

[5] BoM, (2006a). Living with drought. Australian Bureau of Meteorology. Avai lable at http://www.bom.gov.au/climate/drought/ livedrought.shtml.

[6] BoM. (2006b). Severe tropical cyclone Larry. Queensland Regional Office, Australian Bureau of Meteorology. Available at http:// www.bom.gov.au/weather/qld/cyclone/tc_larry/
[7] BoM. (2011). Special climate statement 24. An extremely wet end to 2010 leads to widespread flooding across eastern Australia. Available at http://www.bom.gov.au/climate/current/statements/scs24.pdf.

[8] Buishand, T. A. (1982). Some methods for testing the homogeneity of rainfall records. J. Hydrol. 58: 11-27.

[9] Central Statistical Agency. (2005). Statistical abstract of Ethiopia. Central Statistical Authority. Addis Ababa, Ethiopia.

[10] Chaves, M.. M., Maroco, J. P. and Pereira, J. S. (2003). Understanding plant responses to drought-from genes to the whole plant. Func Plant Bio 30: 239-264.

[11] De Lu1's, M., Gonza'lez-Hidalgo, J. C., Raventos, J., Sanchez, J. R. and Cortina, J. (1999). Spatial analysis of rainfall trends in the region of Valencia (East Spain). Int. J. Climatol. 20: $1451-1469$.

[12] Cheung, W. H., Senay, G. B. and Singh, A. (2008). Trends and spatial distribution of annual and seasonal rainfall in Ethiopia. Int. J. Climatol. 28: 1723-1734. http://dx.doi.org/10.1002/joc.1623.

[13] Conway, D. (2000). Some aspects of climate variability in the northeast Ethiopian highlands-Wollo and Tigray. SINET: Ethiopian J. Sci. 23 (2): 139-161.

[14] Food and Agriculture Organization of the United Nations (2006). The State of Food Insecurity in the World. Rome, Italy.

[15] Gardner, R.. H., Hargrove, W. G., Turner, M. G. and Romme, W. H. (1996) Climate change, disturbances and landscape dynamics. In: Global Change and Terrestrial Ecosystems (Ed. by B. Walker and W. Steffen), Cambridge University Press, Great Britain, 149-172.

[16] Gebreegziabher, Z., Stage, J., Mekonnen, A., and Alemu, A. (2011). Climate change and the Ethiopian economy: A computable general equilibrium analysis. Environment for Development Discussion Paper Series, p. 24.

[17] Gonzalez-Rouco, J. F., Luis, J. J., Quesada, V., and Valero, F. (2001). Quality control and homogeneity of precipitation data in the southwest of Europe. J. Climate. 14: 964-978.

[18] Gebre Hadgu, Kindie Tesfaye, Girma Mamo and Belay Kassa (2013). Trend and variability of rainfall in Tigray, Northern Ethiopia: Analysis of meteorological data and farmers' perception. Acad. J. Agric. Res. 1 (6): 088-100.

[19] Hagos, F., Makombe, G., Namara, R. E., and Awulachew, S. B. (2009). Importance of irrigated agriculture to the Ethiopian economy: Capturing the direct net benefits of irrigation. Colombo, Sri Lanka: Int. Water Manage. Inst. p. 37. (IWMI Research Report 128).

[20] Hassan, R. (2006). Impacts of climate change on Crop farming in Ethiopia. In: Measuring the economic impact of climate change on Ethiopian agriculture: Ricardian approach, CEEPA Discussion paper No. 21, CEEPA, University of Pretoria, South Africa.

[21] Houghton, J. T., Ding, Y., Griggs, D. J., Noguer, M., van der Linden, P. J., and Xiaosu, D. (2001) Climate change 2001: the scientific basis. Contributions of Working Group I to the Third Assessment Report of the Intergovernmental Panel on Climate Change. Cambridge University Press, Cambridge, $881 \mathrm{pp}$. 
[22] IPCC-TGCIA. (1999). Guidelines on the use of scenario data for climate impact and adaptation assessment. Version 1. Prepared by Carter TR, Hulme $M$, and Lal $M$. Intergovernmental Panel on Climate Change, Task Group on Scenarios for Climate Impact Assessment, p. 69.

[23] Karpouzos, D. k., Kavalieratou, S., Babajimopoulos C (2010). Trend analysis of Precipitation data in Pieria Region (Greece). European Water, 30: 31-40.

[24] Kulkarni, A., and Von Storch, H. (1995). Monte-Carlo experiments on the effect of serial correlation on the MannKendall test of trend. Meteorologische Zeitschrift. 4 (2): 82 85 .

[25] Lucier, A., Palmer, M., Mooney, H., Nadelhoffer, K., Ojima, D., and, F. (2006). Ecosystems and climate change: research priorities for the U.S. Climate Change Science Program. Recommendations from the Scientific Community. Report on an Ecosystems Workshop, prepared for the Ecosystems Interagency Working Group. Special Series No. SS-92-06, University of Maryland Center for Environmental Science, Chesapeake Biological Laboratory, Solomons, $50 \mathrm{pp}$.

[26] National Meteorological Services Agency (NMSA) (2001). Report submitted to initial national communication of Ethiopia to the United Nations Framework Convention on Climate Change (UNFCCC), Addis Ababa, Ethiopia.

[27] Ngongondo, C., Yu-Xu, C., Gottschalk, L., and Alemaw, B. (2011). Evaluation of spatial and temporal characteristics of rainfall in Malawi: a case of data scarce region. Theor. Appl. Climatol. DOI 10.1007/s00704-011-0413-0.

[28] Onoz, B., and Bayazit, M. (2012). The Power of Statistical Tests for Trend Detection. Turkish Journal of Engineering \& Environmental Sciences 27 (2003), 247-251.

[29] Pidwirny, M. (2006) The carbon cycle. Fundamentals of physical geography, 2nd edn. Available at http://www.physicalgeography.net/fundamentals/9r.html. Accessed 16 January 2012.

[30] Seleshi, Y., and Zanke, U. (2004). Recent changes in rainfall and rainy days in Ethiopia. Int. J. Climatol. 24: 973-983. http://dx.doi.org/10.1002/joc.1052.

[31] Seleshi, Y., and Camberlin, P. (2006). Recent changes in dry spell and extreme rainfall events in Ethiopia. Theor. Appl. Climatol. 83 (1-4): 181-191.

[32] Somerville, C., and Briscoe, J. (2001). Genetic engineering and water. Science 292: 2217.

[33] Stern, R., Rijks, D., Dale, I., and Knock, J. (2006). INSTAT (interactive statistics) climate guide. pp. 330 .

[34] Tabari, H., Marofi, S., Aeini, A., Talaee, P. H., and Mohammadi, K. (2011). Trend Analysis of Reference Evapotranspiration in the Western half of Iran. Agricultural and Forest Meteorology 151, 128-136.

[35] Tesfaye, K., and Walker, S. (2004). Matching of crop and environment for optimal water use: the case of Ethiopia. Phys. Chem. Earth. 29: (15-18): 1061-1067.

[36] Thomson, A. M., Calvin, K. V., Smith, S. J., Kyle, G. P., Volke, A., Patel, P., Delgado-Arias, S., Bond-Lamberty, B., Wise, M. A., Clarke, L. E., and Edmonds, J. A. (2011) RCP4. 5: a pathway for stabilization of radiative forcing by 2100 . Clim Chang 109: 77-94.

[37] Tosic, I., and Ukaseviç, M. (2005). Analysis of precipitation series for Belgrade. Theoretical andApplied Climatology 80, $67-77$

[38] U.S. Environmental Protection Agency, http://www.epa.gov/climatechange/science/indicators/weather -climate/temperature.html, Date Accessed 05/18/2012.

[39] Yenigun, K., Gumus, V., Bulut, H. (2008). Trends in stream flow of the Euphrates basin, Turkey. Proc. Inst. Civil Eng. Water Manage. 161: 189-198. doi: 10.1680/wama.2008.161.4.189.

[40] Viste, E., Korecha, D., Sorteberg, A. (2012). Recent drought and precipitation tendencies in Ethiopia. Theor. Appl. Climatol. DOI 10.1007/s00704-012-0746-3. 